\title{
ANATOMI TEORI STRUKTURASI DAN IDEOLOGI JALAN KETIGA ANTHONY GIDDENS
}

\section{ANATOMY OF STRUCTURATION THEORY AND IDEOLOGY OF THE THIRD WAY OF ANTHONY GIDDENS}

\author{
Zainal Abidin Achmad \\ Communication Science, Faculty of Social and Political Sciences, UPN Veteran \\ Jawa Timur, Indonesia \\ E-mail: z.abidinachmad@ upnjatim.ac.id
}

\begin{abstract}
ABSTRAK
Kemunculan teori strukturation oleh Anthony Giddens, merupakan tanggapan terhadap klaim post-strukturalis. Strukturasi menyatakan manusia memiliki kemampuan membuat struktur dan secara sukarela menentukan struktur untuk mereka sendiri, artinya manusia memiliki kebebasan penuh untuk membangun lingkungan hidup sendiri. Salah satu nomenklatur khas dalam teori strukturasi adalah hubungan manusia sebagai "agency" terhadap "struktur" atau institusi. Artikel ini memaparkan hubungan antara nomenklatur dan konsep-konsep dalam teori strukturasi dan memberikan contoh kontektual dan relevan. Gagasan tentang kontinum ruang-waktu memberikan kemudahan untuk memahami fenomena geografis. Perkotaan merupakan arena yang memiliki serangkaian hubungan yang rumit antara manusia dan lingkungannya, seperti: penataan tempat tinggal, mobilitas dalam lingkungan, persaingan ekonomi, pekerjaan dan sebagainya. Pemahaman terhadap kompleksitas teori strukturasi Giddens dapat dimanfaatkan untuk penerapan pembangunan modernitas di dalam masyarakat. Globalisasi, modernitas dan Jalan Ketiga merupakan diskusi yang menarik dan dalam dari pemikiran orisinal dan cerdas Anthony Giddens berikutnya. Jalan Ketiga menjelma sebagai ideologi politik tengah diantara dua kutub idelogi sosialisme kiri dan kapitalisme kanan.
\end{abstract}

Kata Kunci: Agensi; Dualitas; Modernitas; Sosiologi Pembangunan; Struktur; Strukturasi

\begin{abstract}
The emergence of the structuration theory by Anthony Giddens is a response to post-structuralist claims. Structuration states that humans can create structures and voluntarily determine structures for themselves, meaning that humans have complete freedom to build their environment. One of the standard nomenclatures in structuration theory is the relationship of humans as "agencies" to "structures" or institutions. This article describes the relationship between nomenclature and concepts in structuration theory and provides contextual and relevant examples. The idea of a space-time continuum makes it easy to understand geographical phenomena. Urban is an arena that has a complex set of relationships between humans and their environments, such as housing arrangement, mobility in the environment, economic competition, and work. An understanding of Giddens's structuration theory's complexity can utilize modernity development in society. Globalization, modernity, and the Third Way are exciting and in-depth discussions from Anthony Giddens' original and intelligent thinking. The Third Way manifests as a middle political ideology between the two ideologies of left socialism and the right capitalism.
\end{abstract}

Keywords: Agency; Duality; Modernity; Sociology Of Development; Structuration; Structure

\section{PROFIL ANTHONY GIDDENS}

Anthony Giddens lahir tahun 1938 di Edmonton, sebuah kota di kawasan London utara. Ketika belajar di London School of Economics (LSE), ia mengambil tesis tentang masalah sosiologi olah raga dan berlanjut 
mengabdi sebagai pengajar hingga menduduki posisi sebagai direkturnya. Sebelum menjadi direktur di LSE, Giddens pertama kali mengajar di The University of Manchester dan bertemu dengan Nobert Elias dengan karyakarya yang sangat mempengaruhi keilmuannya untuk mengajar di King's College of Cambridge dan University of California, Santa Barbara (Giddens, 1992).

Selain dipilih sebagai anggota kehormatan di King's College of Cambridge, Anthony Giddens memperoleh gelar profesor bidang Sosiologi dari University of Cambridge. Selama dua puluh tahun menjadi pengajar, Giddens sangat produktif menulis puluhan karya ilmiah. Berkat puluhan bukunya, Giddens menjadi salah satu sosiolog terkemuka dan menahbiskan dirinya sebagai ilmuwan yang melahirkan teori sosial yang berpengaruh di era modern. Teori dan ideologi yang dilahirkan Giddens merupakan kombinasi pemahaman yang cermat dan genius terhadap pemikiran sosial klasik dengan kepekaannya memahami isu-isu sosial yang kontemporer. Hasil pemikiran Giddens berdasarkan dua pijakan masa perkembangan ilmu sosial tersebut disatukan dalam sebuah rencana kerja dengan sasaran khusus yaitu melakukan kritik atas berbagai kelemahan pemikiran dan teori sosial tradisional sekaligus mengembangkan teori baru untuk dapat menjelaskan isu-isu dan realitas sosial kontemporer. Realitas sosial selayaknya didekati, dipahami, diselesaikan secara multi-perspektif dan pantang dipahami melalui pendekatan yang monolitik (Beilharz, 1991).

Pemikiran teoritik Giddens diakui telah melampaui posisi pemikiran tradisional yaitu sosiologi individualis dan sosiologi determinis. Sementara praktis politiknya Giddens dinilai sebagai radikalisme yang secara tajam mengkritik aliran kiri tradisional (sosialisme partai buruh) dan aliran kanan moderat (liberalisme Thatcher) (Giddens, 1994).

Seiring dengan buku-bukunya yang telah diterjemahkan ke dalam dua puluh dua bahasa, pengikut pemikiran Giddens semakin bertambah. Uniknya, Giddens tidak terlalu dikenal di Perancis karena hanya ada dua buku yang diterjemahkan ke dalam bahasa Prancis. Berbagai karya intelektualnya yang mengagumkan, telah membangkitkan minat berbagai pihak untuk mengkaji dan mendiskusikan pemikirannya dari berbagai dimensi. Dari berbagai buku yang ditulisnya ada empat terbitan buku yang mengurai pemikiranpemikirannya dengan sangat jelas, dalam bentuk terbitan tunggal maupun rangkaian terbitan (Giddens, 2006).

Terbitan pertama adalah rangkaian dua buah buku yang diterbitkan oleh Giddens, berisikan kritik terhadap studi sosiologi klasik. Buku tersebut adalah Capitalism and Modern Social Theory (Giddens, 1971) dan The Class Structure of the Advanced Societies (Giddens, 1973) yang memfokuskan kritik terhadap 
karya-karya Durkheim, Marx dan Weber. Terbitan kedua adalah buku yang berjudul New Rules of Sociological Method yang berisikan pengajuan sebuah teori yang dinamai "Teori Strukturasi." Buku ini menjelaskan pernyataan posisi teori Anthony Giddens di antara belantara teori-teori sosial lainnya (Giddens, 1976). Selanjutnya Giddens mengelaborasi teorinya ke dalam terbitan ketiga berupa rangkaian tiga buah buku yang diterbitkan secara beruntun, yaitu: Central Problems in Social Theory (Giddens, 1979), A Contemporary Critique of Historical Materialism (Giddens, 1981), dan The Constitution of Society (Giddens, 1984). Terbitan keempat adalah rangkaian dua buku yang berjudul The Third Way dan Beyond Left and Right.

The Third Way merupakan buku genial yang sangat menyedot perhatian dari berbagai kalangan, terutama dari akademisi dan politisi tingkat internasional. Beberapa pemimpin dunia yang mempraktikkan pemikiranpemikiran genius Anthony Giddens dalam kebijakan politiknya, antara lain: Perdana Menteri Inggris Tony Blair dan Kanselir Jerman Kanselir Jerman, Gerhard Schroeder (Hutton and Giddens, 2000). Buku Beyond Left and Right, merupakan karya tulis terpenting karena menjadi dermaga bagi berlabuhnya konsep-konsep dan pemikiran yang terkandung dalam buku The Third Way. Semua pemikiran Anthony Giddens mengenai The Third Way sebagai sebuah genealogi historis yang mendokumentasikan gelora paradigmatik, menjadi lebih terbuka arah dan implementasinya dalam buku Beyond Left And Right (Giddens, 1994).

Karya-karya Giddens pun menumbuhkan perdebatan luas di kalangan akademisi di banyak tempat. Pada perdebatan-perdebatan ilmiah tersebut, Giddens hadir dan berpartisipasi. Perdebatan tersebut dapat ditelusuri dalam berbagai buku berikut (Giddens and Held, 1982; Clark, Modgil and Modgil, 1990; Bryant and Jary, 1991; Beck, Giddens and Lash, 1994; Giddens and Pierson, 1998).

Meskipun Giddens mengklaim tentang konsistensi karyanya seputar strukturasi, namun pada sebagian besar tulisan-tulisan berikutnya, Ia telah mengalihkan fokusnya dari diskusi seputar teori strukturasi. Pada karya-karya berikut ini: The Consequences of Modernity (Giddens, 1990), Modernity and Self Identity (Giddens, 1991), dan The Transformation of Intimacy (Giddens, 1992), banyak mengkaji perubahan karakter modernisasi di tingkat masyarakat hingga individu. Gagasan-gagasan Giddens di sini lebih banyak berkaitan dengan globalisasi dan Risk Society (Beck, 1992), yang lebih dalam dikupas di sumbangan tulisan pada Reflexive Modernization (Beck, Giddens and Lash, 1994), Runaway World (Giddens, 1999) dan Global Capitalism (Hutton and Giddens, 2000).

Giddens kemudian meningkatkan keterlibatannya dalam politik praktis, dengan menjadi penasehat pemerintah Inggris dari tahun 1997. Keterlibatan 
aktifnya dalam politik, juga di tuangkan dalam berbagai karya, antara lain: Beyond Left and Right (Giddens, 1994), The Third Way (Giddens, 1998), The Third Way and its Critics (Giddens, 2000), Where Now for New Labour? (Giddens, 2002), Europe in the Global Age (Giddens, 2007a) dan Over to You, Mr Brown-How Labour Can Win Again (Giddens, 2007b).

\section{KONTEKS LAHIRNYA TEORI STRUKTURASI: KRITIK ANTHONY GIDDENS TERHADAP SOSIALISME DAN KAPITALISME}

Sosialisme dan kapitalisme telah mengalami kegagalan sebagai referensi ideologi, karena tidak memuaskan dalam usaha mewujudkan sistem sosial. Akibat kegagalan itu, kedua ideologi tersebut layak didepak dari arena sosial, ekonomi, dan politik. Dunia membutuhkan ideologi yang memiliki semangat baru, nafas baru ajaran baru dan konsep kehidupan baru yang mementingkan nilai-nilai kemanusiaan. Sosialisme dan kapitalisme pada awal kemunculannya seolah mampu menyelesaikan berbagai persoalan dunia, namun kenyataannya mereka tidak bisa bekerja sendiri. Optimisme dua ideologi tersebut adalah dapat memberikan jawaban persoalan dunia dan mampu menjamin tatanan masyarakat masa depan yang lebih baik.

Kegagalan tersebut utamanya karena keduanya masih berakar dari masa enlightenment, berupa pemikiran-pemikiran pada konteks abad 18 . Sementara saat ini, dunia berada pada tahap radical modernity. Suatu kemustahilan untuk menjelaskan dunia modern melalui pemikiran masa lalu. Pemikiran harus menyesuaikan dengan kontek zaman, pemikiran harus menjangkau dan mengatasi perkembangan dunia yang berubah pesat, yang diistilahkan Giddens sebagai radical modernity. Istilah yang lebih tepat dan lebih baik daripada menggunakan sebutan post modernism (Giddens, 1998).

Respon Giddens terhadap modernitas mengajak banyak pihak untuk merumuskan kembali misi dan visi manusia dalam menghadapi perubahan dan persoalan dunia yang seolah bergerak tanpa kendali. Giddens menyarankan untuk melakukan upaya kreatif meredakan ketegangan antara ideologi kiri dan ideologi kanan dengan melupakan kecenderungan pembelaan terhadap kebenaran ideologi masing-masing. Hal terpenting adalah mencari solusi untuk menyusun tata dunia baru yang lebih manusiawi (Giddens, 1998).

Bagian paling menarik dalam pemikiran Giddens ketika membaca realitas sosial adalah pada upayanya membuka ruang untuk berdialog sekaligus menawarkan gagasan yang memperkaya, bukan sekadar menolak atau menerima pemikiran yang telah ada sebelumnya. Giddens melakukan dialog dalam berbagai bukuya pada saat berproses menelusuri dan 
menemukan sintesis terhadap realitas globalisasi. Globalisasi selayaknya mendapatkan kritik atas dampak negatif yang ditimbulkannya, sekaligus kita tidak menerima globalisasi apa adanya. Fokus pemikiran manusia harus siap untuk memberikan jalan terbaik agar tidak terjebak pada fanatisme ideologi, dan terus berupaya menemukan alternatif solusi pada setiap kebuntuan (Giddens, 1998).

Persoalan dunia tidak dapat diselesaikan hanya berkutat pada pembelaan terhadap kebenaran ideologi kanan atau kiri. Kita secara elegan harus mampu menyusun tata kehidupan masyarakat melalui pencarian titik temu di antara berbagai perbedaan untuk mendapatkan gagasan baru, orisinal dan konstruktif. Ideologi kanan maupun kiri secara sendirian diyakini tidak sanggup mengurai dan menyentuh akar permasalahan sosial, seperti: kerusakan lingkungan, migrasi sosial, homoseksual, harmoni keluarga dan masalah lainnya, karena memang membutuhkan kerjasama berbagai pihak (Giddens, 1998).

Sosialisme dan kapitalisme tidak bisa lepas dari perspektif konflik, sehingga klaim kebenaran masing-masing, hanya akan mempertegas bipolaritas pandangan. Salah satunya bahwa sosialisme lahir sebagai reaksi terhadap bahaya kapitalisme. Sosialisme meyakini bahwa perubahan dapat dilakukan hanya melalui konflik dengan menghilangkan kelas penindas untuk menciptakan tatanan masyarakat berkeadilan (Giddens and Held, 1982). Masyarakat kapitalis menyimpan persoalan besar yang semakin memburuk. Kebebasan pasar yang menjanjikan datangnya pertumbuhan ekonomi, di saat yang sama mengakibatkan tingginya kemerosotan ekonomi. Keganasan sifat yang dimiliki kapitalisme pasar bebas hanya menguntungkan sebagian kecil masyarakat dan gagal mendorong kolektivisme. Sistem kapitalisme justru mengalami kegagalan di tempat lahirnya, yaitu Western (Adams, 2002).

Kapitalisme menumbuhkan persaingan yang tidak sehat, karena kelompok masyarakat pemilik modal dapat dengan mudah menyingkirkan kelompok masyarakat yang memiliki keterbatasan modal, kesempatan dan pengetahuan (Mashud, 2010). Dominasi kelompok pemilik modal menyebabkan sistem kapitalisme yang rawan memunculkan ketimpangan sosial karena pertumbuhan hanya terpaku pada yang kuat. Hal ini berakibat pada ketidakadilan dalam kompetisi (Achmad and Alamiyah, 2015). Sistem kapitalisme mendorong produsen berusaha mencapai efisiensi setinggi mungkin dan mencapai produk sebesar-besarnya untuk bisa bertahan (Raharjo, 1999). Prinsip yang memungkinkan orang untuk mengeruk keuntungan sebanyak- banyaknya bagi dirinya. Ideologi seperti ini mengabaikan campur tangan Tuhan terhadap segala aktivitas manusia (Sasono, 1998).

Kaum kapitalis mengandalkan kompetisi bebas dalam rangka mengejar 
dan meningkatkan kemakmuran. Kompetisi bebas menyerahkan kegiatan ekonomi pada pasar. Kekuatan pasar akan dibimbing oleh invisible hand yang mengarahkan perilaku produsen tentang barang apa yang seharusnya diproduksi. Pada akhirnya kekayaan yang ada pada segelintir orang akan menetes ke bawah (trickle down) kepada anggota masyarakat lain (Fakih, 2004).

Giddens secara tegas mengajukan argumen bahwa tetesan kemakmuran tidak akan pernah terwujud. Kesenjangan dan keserakahan yang justru muncul, dengan dampak pada tragedi kemanusiaan. Persaingan bebas malah menjadi ancaman karena mengakibatkan eksploitasi tanpa kendali. Pasar menjadi penentu dan pengendali kebutuhan manusia. Berbagai korporasi raksasa seperti Bank Dunia, IMF juga WTO seolah menjadi juru bicara dan representasi penindasan, penjajahan dan berbagai bentuk rekolonisasi (Giddens, 1998). Kapitalisme mengalami kegagalan karena tidak mampu mengatasi die nue unubersichtlichkeit sebuah istilah yang dinyatakan oleh Jurgen Habermas, artinya letupan-letupan perkembangan yang disertai ketidak terdugaan (Hatta, 2000).

Akibat kebobrokan kapitalisme, Hegel dan Marx memberikan argumentasi bahwa communisme society sebagai sebuah puncak peradaban, karena kapitalisme mengalami kebobrokan yang dapat diampuni (Fukuyama, 1992). Sejarah filsafat adalah proses evolusi atau dialektik, bahwa munculnya sebuah tesis berakibat pada kemunculan antitesis, yang berujung pada lahirnya sebuah sintesis. Pada saat berikutnya, sintesis berposisi sebagai tesis yang akan memunculkan antitesis lalu melahirkan sintesis baru. Begitulah siklus yang terjadi. Tetapi teradapat contradictio in terminis, bahwa posisi tesis pada siklus pemikiran yang ketiga, menganggap sejarah (peradaban) tidak melahirkan peradaban yang lain karena sebuah peradaban sudah mencapai puncak (berakhir) setelah ketiga puncak peradaban terwujud (Fukuyama, 1992).

Teori evolusi sosial menjelaskan bahwa "sejarah" dapat dikisahkan dalam "alur cerita" yang menciptakan gambaran kacau balau tentang berkembangnya peristiwa kedalam urutan yang tertata. Sejarah "dimulai“" dari kebudayaan berburu menuju masyarakat bercocok tanam, berlanjut menuju kebudayaan agraris dan menuju puncaknya pada kebudayaan modern di Barat. Teori ini mengalami dekonstruksi melalui pemikiran JeanFrançois Lyotard dan pemikir lain beraliran postmodern. Sejarah tidak memiliki bentuk menyeluruh, karena sejarah tidak bisa dilihat sebagai satu kesatuan yang utuh yang mencerminkan tranformasi (Giddens, 1990).

Sejarah menurut Giddens bukan sebuah urutan peristiwa yang linier ataupun siklus yang berayun seolah pendulum. Sejarah diibaratkan 
sebagaimana sekumpulan orang mabuk. Manusia berada dalam kondisi hidup seperti berjalan terhuyung ke kiri dan kekiri dan bergerak saling silang untuk memburu utopia. Utopia adalah sebuah kondisi yang diidamkan, sebagai kebalikan dari kondisi yang menyengsarakan. Sebuah kondisi yang diharapkan lebih baik daripada kondisi kehidupan yang sedang dijalani saat ini. Cara terbaik dan agung untuk mewujudkan utopia adalah politik (Giddens, 1995). Sebagaimana Giddens yang tidak bersetuju pada pemikiran Marx dan pengikutnya bahwa segala persoalan kejahatan di dunia disebabkan oleh pertentangan kelas antara kapitalis dengan proletar. Kaum kapitalis sebenarnya memang menyengsarakan kaum buruh, tetapi Giddens ragu bahwa kondisi ini serta merta menjadi penyebab timbulnya perlawanan dari para pembela kelestarian alam, pembela hak asasi, pembela perdamaian dan pembela demokrasi. Giddens menghadirkan negara sebagai entitas yang mempunyai kepentingan otonom dari para kapitalis, dalam menjalankan pengawasan dan penjagaan kondisi tersebut (Giddens, 1998).

Dunia membutuhkan gerakan radikalisme politik sebagaimana gagasan Giddens, artinya gerakan untuk melepaskan diri dari cengkraman masa lalu. Radikalisme politik bukanlah revolusi sebagaimana dimaknai oleh ide sosialisme. Makna radikalisme politik adalah pada semangat progresivitasnya bukan menghancurkan tatanan yang ada. Sejarah harus dikuasai untuk kepentingan manusia, keuntungan-keuntungan materialisme dan kapital yang dianggap sebagai pemberian Tuhan bagi segelintir orang, harus dikembangkan dan diatur untuk kemanfaatan dan kesejahteraan bersama (Giddens, 2000). Radikalisme bukan sekadar menggulirkan perubahan tetapi turut mengendalikan perubahan sehingga dapat menggiring sejarah menuju masa depan. Banyak bukti yang menunjukkan kegagalan negara karena terlalu besar perannya mengintervensi pasar. Atau peran negara menjadi tidak ada (Mashud, 2001). Bukan berarti kita serahkan sepenuhnya keadilan kepada pasar dan menganggap kapitalisme dalam bentuk neoliberalisme dapat mengatasi persoalan (Giddens, 1998).

Posisi peran negara menurut Giddens, tidak boleh terlalu dominan terhadap pasar, tetapi negara harus fleksibel untuk mengakomodasi kepentingan investor dalam kerangka untuk bersama mendapatkan keuntungan. Kesediaan bekerja sama bukanlah sebuah ancaman melainkan solusi untuk mendapatkan hasil terbaik, daripada saling berposisi sebagai lawan antara kepentingan negara dengan kepentingan investor (Giddens, 2000).

Jalan ketiga merupakan jalan tengah antara kapitalisme dan sosialisme. Sosialisme adalah perwujudan ketidakpuasan terhadap kesenjangan dalam masalah pendapatan akibat kegilaan kapitalisme. Tetapi kita perlu memahami 
pemikiran sosialisme dan kapitalisme sebagai sebuah perspektif untuk memahami sekaligus menjelaskan realitas sosial ekonomi politik yang ada (McClelland, 2005). Apabila kita menggunakan satu pemikiran saja, maka kita akan terjebak pada nasionalisme yang sempit, fanatisme berlebihan dan mempertegas pembagian blok dunia yang berujung pada meningkatnya ketegangan dunia (Giddens, 1994).

\section{GLOBALISASI, DEMOKRASI DAN JALAN KETIGA}

Ketegangan dunia akibat bipolaritas antara praktik sosialisme dan kapitalisme, melahirkan paradigma ideologi tengah yang diberi nama "Jalan Ketiga" (The Third Way). Ideologi yang dilahirkan oleh Anthony Giddens ini merupakan ideologi alternatif yang berusaha menjawab persoalan kemanusiaan yang seharusnya menjadi tujuan utama dari kehadiran sebuah ideologi (Giddens, 1998). Ideologi Jalan Ketiga lahir dengan mengusung semangat kemanusiaan, merupakan wacana politik global yang menjadi respon atas janji muluk penciptaan masa depan manusia yang diberikan oleh ideologi sosialisme dan kapitalisme. Kegagalan sosialisme dan keangkuhan kapitalisme yang berkembang dalam kerja politik dunia, justru saling menjatuhkan dan berujung pada pudarnya nilai-nilai kemanusiaan di genggaman tangan kaum borjuis dan proletar (Giddens, 1994).

Jalan Ketiga mengajak kita untuk melampaui ideologi kiri atau kanan, berdasarkan asumsi bahwa keduanya telah mengalami kegagalan untuk membawa peradaban dunia menuju kedamaian dan keharmonisan. Kedamaian dan keharmonisan adalah ruh dari seluruh ideologi apapun di dunia. Sosialisme dan kapitalisme perlu dipinggirkan sebagai titik tolak dalam pembangunan peradaban dunia yang lebih akomodatif terhadap tujuan kemanusiaan sebuah ideologi. Jalan Ketiga menunjukkan keberpihakan dan semangat Giddens terhadap humanisme sebagai jantung beroperasinya pembangunan tata dunia baru bagi terciptanya menciptakan masa depan kehidupan manusia yang berkeadilan (Giddens, 1994).

Sejak saat itulah, Jalan Ketiga dimanifestasikan ke dalam berbagai kebijakan politik beberapa negara. Sebagaimana kumpulan hasil survei dalam buku berjudul "New Times: The changing face of politics in 1990s," menunjukkan bahwa pengaruh ideologi kanan dan kiri semakin menurun secara signifikan (Hall and Jacques, 1990). Beberapa negara industri di dunia telah mempraktikkan budaya politik baru Jalan Ketiga sebagai respon terhadap perubahan sosial dan ekonomi. Manifestasi kebijakan politik ini berbeda dengan model politik tradisional yang mengandalkan sosialisme dan kapitalisme (Giddens, 2000). Kumpulan penelitian pada tahun 1990, menjadi landasan bagi prediksi Stuart Hall tentang lahirnya sebuah Masa 
Baru (New Times) yaitu tranformasi politik sosialis. Indikasi lahirnya New Times adalah bergesernya produksi industri ke teknologi informasi, melemahnya pertentangan seksualitas, kaburnya batasan gaya hidup dan melemahnya peran politik kelas (Giddens, 2000).

Sebagaimana diakui Giddens bahwa pemikiran Jalan Ketiga sejalan dengan harapan Carol C. Gould untuk memperluas praktik teori demokrasi tidak hanya di ranah politik melainkan ke ranah ekonomi dan sosial (Gould, 1990). Jalan Ketiga sebagai kerangka kerja untuk membangun sosial demokrasi, bukan sekadar mencari kelemahan sosialisme dan kapitalisme, melainkan mengaktualisasikan ke dalam dunia kontemporer dipenuhi ketidakpastian (Giddens, 2000). Kelahiran Jalan Ketiga adalah harapan yang muncul akibat empat turbulensi dunia di akhir abad ke-20. Pertama, sosialisme mengalami mati suri di Eropa Timur sejak revolusi 1989. Kedua, globalisasi yang mendominasi dunia sejak rezim Ronald Reagan (AS) dan Margaret Thatcher (Inggris). Ketiga, akibat krisis ekonomi yang menerpa Asia Timur pada tahun 1997, dunia telah meninggalkan kebijakan ekonomi neoliberal. Keempat, berkembangnya demokrasi sosial di kawasan Eropa Barat pada kurun waktu 1990 hingga 2000 (Hutton and Giddens, 2000).

Jalan Ketiga menyerukan reformasi politik pada dua aspek, yaitu (1) penciptaan kebaikan bersama (common good) melalui pembaruan etos dan praksis politik. (2) negara bangsa perlu ditataulang (reconstruction) sebagai sebuah komunitas (Giddens, 2000). Kebaikan bersama hanya dapat tercipta bersama virtus: keadilan, solidaritas, keberanian dan kebajikan. Gagasan Jalan Ketiga adalah upaya menyeru manusia untuk kembali pada nilai-nilai universalisme tentang kepedulian nasib sesama manusia. Peran negara dalam manifestasi Jalan Ketiga haruslah lincah menjalankan developmentalisme dan tidak menciptakan berbagai regulasi yang mematikan kreativitas warga negara. Peran negara tidak boleh terlalu besar karena dapat mempersempit ruang publik, menjadikan masyarakat semakin pasif, dan ide-ide pembangunan negara menjadi tidak terkomunikasikan dengan baik. Jalan Ketiga memiliki kepentingan dengan memangkas rantai birokrasi yang terlalu mengikat secara formal (Giddens, 1998).

Jalan Ketiga merupakan respon terhadap globalisasi, perkembangan teknologi, kemajuan ilmu pengetahuan, masalah ekologis relasi manusia dengan alam, dengan membangun kembali solidaritas sosial dan memperkuat nilai-nilai kosmopolitan dengan mendasarkan pada tujuan luhur ideologi. Sikap ini disebut sebagai konservatisme filosofis (Giddens, 2000). Ideologi politik menjadi acuan untuk merespon dunia, pada saat dunia mengalami berbagai transformasi. Kemajuan ilmu pengetahuan mengubah kehidupan alamiah, sedangkan tradisi dan kebiasaan telah semakin luntur. 
Untuk saat ini, demokrasi diakui sebagai sebuah sistem politik dunia yang menjamin terwujudnya relasi yang bebas dan setara: (1) Demokrasi dapat mengembangkan potensi-potensi dan ekspresi beragam kualitas orang. Setiap individu menghargai kapabilitas orang lain. (2) Demokrasi menjamin perlindungan warga negara dari kesewenangan dan penindasan oleh otoritas politik dan kekuasaan. Keputusan politik harus melalui negosiasi dengan warga negara yang terdampak akibat keputusan tersebut. (3) Demokrasi menghargai keterlibatan individu dalam penentuan syarat atau aturan komunitas. Dalam konteks ini, individu-individu "dipaksa" untuk sanggup menerima karakter asli dan pendapat rasional orang lain. (4) Demokrasi menjamin perluasan kesempatan ekonomi (individu, kelompok, perusahaan) untuk mengembangkan sumber daya yang ada (Giddens and Held, 1982).

Secara singkat Giddens menyatakan bahwa demokrasi menjamin otonomi, yaitu setiap individu mendapat kepastian untuk refleksi diri dalam melakukan self determination. Individu dapat menilai, memperhitungkan, memilih, menimbang dan bertindak secara otonom. Praktik otonomi tidak dapat berkembang, apabila masih berlaku kepemilikan dan tradisi istimewa dalam hal hak dan kewajiban politik (Giddens, 1992). Demokrasi membuka kesempatan diskusi, mediasi, negosiasi dan kompromi terhadap berbagai perbedaan argumen untuk menetapkan keputusan politik untuk tatanan yang lebih baik Salah satunya diperlukan institusi yang menjadi representasi warga negara yang memungkinkan publik memberikan andil bagi penentuan kebijakan (Giddens and Held, 1982). Demokrasi tidak berdasarkan pada primordialisme, suku, agama dan ras kelompok. Demokrasi menjadi dasar perwujudan tatanan masyarakat madani yang menyediakan mekanisme penyelesaian konflik melalui wacana universal dalam relasi kesederajatan, termasuk di dalamnya adanya pengakuan hak asasi manusia.

Pengembangan demokrasi perlu memahami struktur masyarakat modern yang berlangsung saat ini, senyampang turut berpartisipasi dalam berbagai tranformasi yang sedang berkembang. Refleksi atas kondisi manusia dalam masyarakat modern menjadi penekanan Giddens. Modernitas sebaiknya tidak dilihat semata dari logika tunggal, sebagaimana logika politik, kapital atau multikultural. Tidak seperti Marx memahami modernitas melalui kapital, Weber logika rasionalisasi, Durkheim melalui interaksi sosial. Ketika manusia memikirkan dunia modern, setidaknya mempersiapkan diri untuk mengartikulasikan logika sebagaimana susunan atap genteng (imbriguees). Masyarakat modern bukanlah sebuah sistem integral yang bergerak karena satu sistem tunggal dan tidak membentuk satu kebersamaan tunggal. Memahami masyarakat modern melibatkan sejumlah logika dan interferensi berbagai tren. Modernitas memiliki sifat multidimensional (Giddens, 1990). 
Giddens mengajak kita untuk berfikir luas dan bervisi global sehingga dapat menangkap persepsi sesungguhnya. Manusia saat ini hidup pada zaman yang "meradikalisasi" modernitas (Giddens, 1990, 1991). Masyarakat yang mendunia mendorong modernitas seperti "mesin gila" yang berjalan tanpa kendali manusia. Diperlukan kesadaran kolektif untuk dapat mengemudikan perubahan dan membatasinya, bahkan sanggup mengontrol pasar bebas. Perubahan visi inilah yang menjadi manifesto Giddens yang dinamai The Third Way sebagai kerangka untuk memahami dan mengantisipasi dampak negatif modernitas.

\section{METODE KERJA, AGENDA POLITIK DAN STRATEGI POLITIK JALAN KETIGA}

Terdapat enam kerangka ideologi Jalan Ketiga sebagai metode kerja radikalisme politik Ing berusaha dibentuk kembali berdasarkan konservatisme filosofis. Pada sebagian hal, beberapa nilai inti yang ada, mempertahankan sebagian pemikiran sosialis.

1. Memiliki keniscayaan untuk peduli dalam perbaikan solidaritas sosial yang mengalami kehancuran (damaged solidarity). Untuk itu diperlukan pelestarian beberapa nilai tradisi secara selektif, terkadang pelestraian tradisi tersebut menggunaan istilah atau penamaan yang baru. Dalil kepedulian ini menjadi kerangka kerja bersama yang diterapkan pada setiap aksi. Bukan saja kerja di tingkat individual, komunitas dan negara melainkan juga pada aksi kerja pada sistem global.

2. Menyatakan pengakuan terhadap pentingnya politik kehidupan (life politics) dalam tatanan formal. Mempertahankan politik emansipatoris yang diadposi dari ideologi politik kiri, yang menjamin kebebasan dari cengkraman tradisi arbriter, kekuasaan abriter, dan tekanan deprivasi material. Politik emansipatoris menyediakan politik kesempatan hidup (politic of life chance) untuk menuju terciptanya otonomi aksi.

3. Memiliki tanggung jawab menghadirkan konsepsi politik generatif, akibat meningkatnya refleksivitas sosial. Politik generatif menghubungkan negara dengan mobilisasi refleksif masyarakat untuk berada dalam ruang yang sama. Serta memungkinkan upaya mewujudkan berbagai harapan individu dan kelompok menjadi kenyataan (make things happen), bukan sekadar menerima keyataan (have things happen) dalam konteks tujuan sosial.

4. Perlunya membentuk demokrasi radikal yang bersifat dialogis, sebagai akibat dari munculnya berbagai kelemahan demokrasi liberal dalam tatanan sosial sebagai refleksi dunia global. Sifat dialogis dalam demokrasi merupakan solusi penyelesaian melalui cara damai untuk menyelsaikan masalah daripada melalui cara kekerasan. Semakin meluasnya praktisi demokrasi dialogis dapat mendorong proses pendemokrasian demokrasi, 
salah satunya dengan tranparansi pengelolaan pemerintahan secara lebih luas yang dilakukan oleh pemerintah.

5. Memiliki kesediaan untuk memikirkan terwujudnya negara sejahtera (welfare state) secara lebih fundamental, akibat semakin meluasnya kemiskinan global.

6. Program politik radikal harus bersiap menghadapi peran kekerasan dalam penyelesaian masalah kemanusiaan, melalui tindakan dialog sebagai pengganti kekerasan (Giddens, 1994).

Giddens sangat memperhatikan pentingnya perjuangan mewujudkan masyarakat madani, karena masyarakat madani bukanlah kondisi yang tercipta begitu saja, taken for granted. Diperlukan perjuangan dan proses sejarah yang panjang dan bersinambung untuk dapat membentuk masyarakat madani. Prasyarat dasar yang harus ada untuk mewujudkan masyarakat madani, adalah keberadaan pemerintahan yang demokratis melalui proses pemilihan demokratis untuk dapat berkuasa dan menjalankan nilai-nilai responsibillty, security, dan resilience bagi masyarakatnya (Giddens, 1994). Pemerintah memberikan peluang kreativitas warga negara secara luas, untuk membangun kemajuan di wilayahnya.

Jalan ketiga memiliki agenda untuk mewujudkan masyarakat madani yang berkeadilan. Agenda ini dijadikan pedoman oleh community workers dalam menjalankan misi dan aksinya di tengah masyarakat. Secara garis besar Jalan Ketiga memiliki dua agenda, yaitu: (1) berjuang untuk mewujudkan persamaan, perlindungan dan keberpihakan kepada kelompok masyarakat yang lemah, mendorong kebebasan (freedom) sebagai kemandirian yang otonom, untuk memperoleh hak harus melaksanakan tanggung jawab, pemberlakuan otoritas harus melalui proses demokrasi, pluralisme haruslah kosmopolitan, dan berdasarkan filsafat yang konservatif. (2) mewujudkan negara demokratis baru yaitu negara tanpa musuh, sistem ekonomi campuran yang baru, demokrasi dialogis dan kekeluargaan, masyarakat madani yang aktif, kesetaraan dan kesejahteraan sebagai inklusivitas, bangsa yang kosmopolitan dan negara yang berinvestasi sosial (Giddens, 1998).

Strategi menjalankan politik Jalan Ketiga, meliputi empat hal yaitu: (1) Membantu masyarakat dalam mencapai tujuan pemerintah melalui programprogram peningkatan investasi sosial dan distribusi berbagai layanan sosial dasar secara adil dan meluas. (2) Membantu masyarakat dalam memenuhi kebutuhannya melalui desentralisasi pembuatan kebijakan dan peningkatan brebagai program sosial yang dapat meningkatkan kemampuan masyarakat untuk mewujudkan kepentingannya. (3) Perlindungan hak asasi manusia, kebebasan berorganisasi dan mengeluarkan pendapat, serta penguatan 
struktur hukum lembaga swadaya masyarakat. (4) Tidak abai terhadap wilayah publik dengan menawarkan untuk rekonstruksi dan pembaruan institusi publik. Politik Jalan Ketiga menekankan peran aktif negara dan wilayah publik (Giddens, 1998).

Keberadaan negara adalah memainkan peran mendasar dalam wilayah ekonomi sebagaimana negara berperan dalam wilayah selain ekonomi. Negara tidak menggantikan struktur masyarakat madani dan pasar, tetapi negara diperlukan untuk mengintervensi keduanya. Pemerintahan dalam sebuah negara harus menciptakan stabilitas ekonomi, mengembangkan infrastuktur, memperluas investasi pendidikan, membangun sistem kesejahteraan yang kuat, mengendalikan atau mengurangi jarak ketidaksetaraan (Giddens, 2000). Tiga kunci kekuasaan yaitu pemerintah, kekuatan ekonomi dan kekuatan masyarakat madani, perlu dibatasi kepentingan untuk lebih melayani kepentingan solidaritas sosial dan keadilan sosial. Sebuah tatanan demokratis yang lebih menjanjikan, karena efektivitas pasar tergantung pada berkembangnya kekuatan masyarakat madani.

\section{Strukturalism dan Strukturasi}

Teori strukturasi Anthony Giddens mendasarkan diri pada pengidentifikasian hubungan yang berlangsung antara individu dan institusi sosial. Teori ini meletakkan keseimbangan peran yang dimainkan aktor (manusia) dengan pilihan terbatas yang ada dalam sejarahnya dan yang ada dalam tatanan sosialnya. Di satu sisi, manusia memiliki pengetahuan yang dibatasi dan tidak memiliki seluruh preferensi atas tindakannya. Pada sisi yang lain, manusia adalah pencipta struktur sosial dan penyebab perubahan sosial (Giddens, 1984; Craib, 1992). Teori ini membuktikan keberadaan dualitas manusia antara struktur dan agensi ini daripada menentukan apa yang sebenarnya menyebabkan atau memperkuat keberadaannya.

Agensi dan struktur adalah saling terhubung dan tidak dapat dipisahkan, karena keduanya adalah 'dualitas struktur'. Aktor (manusia) memiliki kemampuan sebagai pencipta struktur masyarakat, melalui pembuatan norma, penyusunan nilai-nilai, dan perancangan penerimaan sosial. Tetapi aktor (manusia) mendapatkan pembatasan dari struktur sosial. Seseorang tidak dapat memilih siapa orang tuanya dan waktu kelahirannya. Giddens menggambarkan struktur sebagai modalitas, berupa seperangkat tata aturan dan berbagai sumber daya yang mengendalikan bahkan mengarahkan tindakan manusia. Tindakan manusia dibatasi oleh aturan, tetapi sumber daya menyediakan fasilitas bagi tindakan manusia (Giddens, 1984; Whittington, 2015).

Strukturasi adalah suatu proses bagaimana aktor mereproduksi struktur, melalui sistem interaksi yang muncul sebagai hasil dari penggunaan struktur. 
Sistem hubungan yang menunjukkan bahwa aturan membatasi interaksi sosial aktor, sementara sumber daya memfasilitasi dan mereproduksi interaksi sosial aktor. Secara universal memang struktur yang berupa nilai-nilai moral, tradisi, impian ideal, bahkan institusi sosial bersifat stabil, namun demikian struktur dapat diubah apabila terdapat tindakan yang tidak disengaja. Misalnya, ketika manusia meninggalkan norma sosial, manusia akan mengganti atau mereproduksi norma sosial lainya dengan cara yang berbeda (Giddens, 1984).

\section{Jenis-jenis Struktur}

Pada sebuah sistem sosial terdapat tiga jenis struktur, yaitu: dominasi, legitimasi, dan signifikasi. Secara stratifikasi struktur, diperoleh gambaran hubungan antara struktur dan sistem interaksi (Craib, 1992). Struktur tingkat pertama adalah signifikasi yang menghasilkan makna melalui pengorganisasian elemen kebahasaan (semantik, interpretatif, dan diskursif). Peran aktor diperluas untuk menafsirkan dan memanipulasi struktur kebahasaan dengan interpretasi berbagai makna (Cloke, Philo and Sadler, 1991). Struktur kedua adalah legitimasi, yaitu tatanan moral berupa norma, nilai, dan standar sosial. Ketika agen individu berinteraksi, mereka menunjukkan makna secara sadar, bawah sadar, atau tidak sadar dari tingkah laku mereka. Berinteraksi dengan cara ini membentuk norma sosial saat ini dan menimbang aturan moral struktur. Apakah suatu tindakan agen dianggap sah atau tidak dalam tatanan sosial, ditentukan oleh struktur legitimasi ini. Struktur ketiga adalah dominasi, yaitu proses produksi dan eksekusi kekuasaan, melalui pengendalian berbagai sumber daya. Giddens mengidentifikasi bahwa kekuatan dominasi dan ketundukan ada dalam hubungan kekuasaan.

Sebagaimana Marx, Giddens juga percaya bahwa sumber daya adalah kendaraan untuk kekuasaan. Marx lebih tertarik pada hubungan antara 'alat produksi' dalam masyarakat kapitalis. Sedangkan Giddens memahami hubungan kekuasaan sebagai bentuk interaksi antara aktor dan struktur. Dalam interaksi ini, sumber daya dapat digunakan sebagai bentuk otoritas yang diilustrasikan oleh hubungan bos dan karyawan. Sumber daya juga dapat digunakan dalam bentuk properti seperti alokasi kekayaan atau properti.

\section{Agensi}

Tindakan dasar manusia dan kegiatan yang dihasilkan, merupakan dua kemampuan yang menentukan manusia sebagai 'Agensi'. Giddens membedakan antara tindakan sebagai perkembangan aksi yang terpisah dan aksi sebagai keterlibatan rendah yang berkelanjutan oleh agen manusia yang berbeda dan otonom (Cloke, Philo and Sadler, 1991). Tindakan individu dapat dirangsang oleh keinginan menyelidiki tindakan sendiri atau proses pemeriksaan diri yang disebut sebagai pemantauan refleksif (Giddens, 1984). Model tindakan Giddens memiliki 
tiga elemen, yaitu pemantauan releksif, rasionalisasi dan motivasi. Setiap elemen memiliki peran spesifik dalam keseluruhan proses aksi. Teori strukturasi menunjukkan bahwa agensi adalah elemen mendasar untuk menciptakan segala macam perubahan. Perubahan dapat dianggap sesederhana gerakan melalui ruang untuk berinteraksi dengan lingkungan baru, perubahan atau kompleksitas interaksi.

\section{Mikro versus Makro}

Struktur sangat penting untuk topik tingkat mikro dan makro. Mengambil contoh yang digunakan sebelumnya tentang pembatasan pilihan orang tua seseorang. Pada tingkat mikro, manusia tidak dapat memilih orang tua. Tetapi pada tingkat makro, manusia memiliki pilihan untuk mempunyai anak. Hubungan yang dibuat individu berada dalam interaksi konstan dan dikendalikan oleh individu itu sendiri. Di sisi lain, individu tidak mampu mengorganisir sebagai masyarakat, tanpa keberadaan organisasi sosial dan negara. Pada tingkat makro ini kita disatukan oleh pola bertahan hidup bersama yang disusun oleh seperangkat standar yang ditentukan seperti hukum negara. Kedua perspektif itu tidak bisa dipisahkan; jika tidak, akan sulit untuk memahami mereka secara terpisah. Ikatan bersama antara individu dan kekuatan eksterior ini menyatukan teori Strukturalisasi Giddens.

\section{KESIMPULAN}

Tujuan utama politik Jalan Ketiga merupakan upaya kesepahaman bersama dalam rangka mencari solusi alternative dari pada sekadar mempertentangkan antara sosialisme dengan kapitalisme. Politik Jalan Ketiga mengunggulkan kepeduliannya pada keadilan sosial dan mendefiniskan ulang kebaikan bersama yang menekankan dua semboyan, yaitu: tidak ada perolehan hak tanpa pelaksanaan tanggung jawab dan tidak ada pemberian otoritas tanpa pemberlakuan demokrasi. Jalan ketiga adalah cara efektif untuk mewujudkan keadilan dan solidaritas sosial karena mampu mengembangkan dan memadukan keuatan berbagai program politik. Jalan ketiga mampu menghadapi ketidaksetaraan dan kekuatan perusahaan dalam dunia kontemporer.

Ideologi Jalan Ketiga dapat menumbuhkan bentuk masyarakat beragam dengan dasar nilai-nilai egalitarian. Politik Jalan Ketiga menjamin kesempatan yang sama dalam memperoleh pendapatan meskipun besarannya berbeda, tetapi sangat peduli terhadap ketidaksamaan penghasilan. Membatasi kemungkinan timbulnya ketidaksetaraan kekayaan dan keuntungan, karena dapat merampas kesempatan generasi berikutnya.

Dualitas agensi dan struktur sangat penting untuk memahami 
kompleksitas yang ada dalam hubungan antara keduanya. Agensi yang berpengetahuan dapat menyimpulkan dari pengalaman lokasi mereka dalam struktur. Kebebasan yang dimiliki suatu agensi dalam lingkungannya bergantung pada konteks agensi tersebut diamati. Agensi memiliki peran penting dalam mengubah struktur ketika terkait perubahan norma, regulasi dan kebijakan.Memahami dualitas dapat secara mudah dengan mengajukan pertanyaan, kapan dan bagaimana perubahan oleh agensi dianggap cukup signifikan untuk mengubah struktur.

\section{ACKNOWLEDGEMENT}

Penulis mendedikasikan artikel ini untuk Prof. Dr. Musta'in, Drs., M,Si., guru besar Sosiologi Universitas Airlangga yang memberikan tugas mencabar teori-teori modernitas dalam mata kuliah "Perubahan Sosial" di semester kedua tahun akademik 2015/2016 pada Program Studi S3 Ilmu Sosial, FISIP Universitas Airlangga. Beliau sekaligus merupakan ko-promotor disertasi penulis.

\section{DAFTAR PUSTAKA:}

Achmad, Z. A. and Alamiyah, S. S. (2015) 'Relation Between Political Economic of Media with the Strategies for Radio Positioning to Maintain the Existence of Commercial Radio (Case Study of JJFM Radio in Surabaya)', in International Conference on Democacy and Accountability (ICoDA). Surabaya: Faculty of Social and Political Science, Universitas Airlangga, pp. 188-193.

Adams, I. (2002) Political Ideology Today. 2nd edn. Manchester: Manchester University Press.

Beck, U. (1992) Risk Society: Towards a New Modernity. London: SAGE Publications Ltd.

Beck, U., Giddens, A. and Lash, S. (1994) Reflexive Modernization: Politics, Tradition and Aesthetics in the Modern Social Order. Stanford, CA: Stanford University Press.

Beilharz, P. (1991) Social Theory: A Guide to Central Thinkers. St Leonards, NSW: Allen \& Unwin.

Bryant, C. G. A. and Jary, D. (eds) (1991) Giddens' Theory of Structuration: A critical appreciation. London and New York: Routledge.

Clark, J., Modgil, C. and Modgil, S. (1990) Anthony Giddens: Consensus and controversy. Consensus. London: Falmer Press.

Cloke, P., Philo, C. and Sadler, D. (1991) Approaching human geography: an introduction to contemporary theoretical debates. London: Paul Chapman.

Craib, I. (1992) Anthony Giddens. London: Routledge.

Fakih, M. (2004) 'Neoliberalisme dan Globalisasi', Al-Manär: Ekonomi Politik Digital Journal, 1(1), pp. 1-12. Available at: https://mirror.unpad.ac.id/orari/library/cd-al-manaar-digilib/bahan/8. EKONOMI POLITIK/3. Neoliberalisme dan Globalisasi.pdf. 
Fukuyama, F. (1992) The End of History and the Last Man. New York: The Free Press.

Giddens, A. (1971) Capitalism and Modern Social Theory: An Analysis of the Writings of Marx, Durkheim and Max Weber. Cambridge: Cambridge University Press.

Giddens, A. (1973) The Class Structure of the Advanced Societies. London: Hutchinson University Library.

Giddens, A. (1976) New Rules of Sociological Method: A Positive Critique of Interpretative Sociologies. 2nd edn. Cambridge, UK: Polity Press.

Giddens, A. (1979) Central Problems in Social Theory: Action, structure and contradiction in social analysis. Basingstoke: Palgrave.

Giddens, A. (1981) A Contemporary Critique of Historical Materialism: Vol. 1 Power, property and the state. Berkeley and Los Angeles: University of California Press.

Giddens, A. (1984) The Constitution of Society. Cambridge, Massachusetts: Polity Press.

Giddens, A. (1990) The Consequences of Modernity. Cambridge, UK: Polity Press.

Giddens, A. (1991) Modernity and Self-Identity: Self and Society in the Late Modern Age. Cambridge, UK: Polity Press.

Giddens, A. (1992) The Transformation of Intimacy: Sexuality, Love and Eroticism in Modern Societies. Palo Alto, CA: Stanford University Press.

Giddens, A. (1994) Beyond Left and Right: The Future of Radical Politics, Journal of Chemical Information and Modeling. Cambridge, UK: Polity Press.

Giddens, A. (1995) Politics, Sociology and Social Theory: Encounters with Classical and Contemporary Social Thought. Stanford, CA: Stanford University Press.

Giddens, A. (1998) The Third Way: The Renewal of Social Democracy. Cambridge, UK: Polity Press.

Giddens, A. (1999) Runaway World: How Globalisation is Reshaping our Lives. London: Profile Books.

Giddens, A. (2000) The Third Way and its Critics. Cambridge, UK: Polity Press.

Giddens, A. (2002) Where Now for New Labour? Cambridge: Polity.

Giddens, A. (2006) Sociology. 5th edn. Cambridge, UK: Polity Press.

Giddens, A. (2007a) Europe in the Global Age. Cambridge: Polity Press.

Giddens, A. (2007b) Over to You, Mr Brown-How Labour Can Win Again. Cambridge: Polity.

Giddens, A. and Held, D. (eds) (1982) Classes, Power, and Conflict: Classical and Contemporary Debates. London and Basingtoke: Macmillan Education.

Giddens, A. and Pierson, C. (1998) Conversations with Anthony Giddens: Making Sense of Modernity. Cambridge, UK: Polity Press.

Gould, C. C. (1990) Rethinking Democracy: Freedom and Social Cooperation in Politics, Economy, and Society. Cambridge: Cambridge University Press.

Hall, S. and Jacques, M. (eds) (1990) New Times: The Changing Face of Politics in 1990s. London: Lawrence \& Wishart. 
Hatta, M. (2000) Sosialisme Religius Suatu Jalan Keempat. Yogyakarta: Kreasi Wacana.

Hutton, W. and Giddens, A. (eds) (2000) Global Capitalism. New York: The New Press.

Mashud, M. (2001) 'Analisis Politik Ekonomi Petani Dalam Struktur Hubungan antara Negara dan Pasar', Masyarakat, Kebudayaan dan Politik, XIV(4), pp. 77-88.

Mashud, M. (2010) Sosiologi Pembangunan. Tangerang Selatan: Universitas Terbuka. Available at: http://www.pustaka.ut.ac.id/lib/wpcontent/uploads/pdfmk/SOSI4411-M1.pdf.

McClelland, J. S. (2005) A History of Western Political Thought, A History of Western Political Thought. London and New York: Routledge. doi: 10.4324/9780203980743.

Raharjo, D. (1999) Islam dan Tranformasi Sosial Ekonomi, Lembaga Studi Agama dan Filsafat. Yogyakarta: Pustaka Pelajar.

Sasono, A. (1998) Solusi Islam Atas Problem Umat. Jakarta: Gema Insani Press.

Whittington, R. (2015) 'Giddens, structuration theory and strategy as practice', in Cambridge Handbook of Strategy as Practice, Second Edition, pp. 145-164. doi: 10.1017/CCO9781139681032.009. 